九州大学学術情報リポジトリ

Kyushu University Institutional Repository

\title{
Effect of Polysaccharides on Rheological Properties of Soy Protein Isolate Emulsion Gels
}

Tsai, Jenn-Shou

Institute of Food Chemistry, Faculty of Agriculture, Kyushu University

Nonaka, Michiko

Institute of Food Chemistry, Faculty of Agriculture, Kyushu University

Yamada, Koji

Institute of Food Chemistry, Faculty of Agriculture, Kyushu University

Murakami, Hiroki

Institute of Food Chemistry, Faculty of Agriculture, Kyushu University

他

https://doi.org/10.5109/23916

出版情報: 九州大学大学院農学研究院紀要. 33 (1/2)，pp.47-60，1988-10. Kyushu University バージョン：

権利関係 : 


\title{
Effect of Polysaccharides on Rheological Properties of Soy Protein Isolate Emulsion Gels*
}

\author{
Jenn-Shou Tsai, Michiko Nonaka, Koji Yamada, \\ Hiroki Murakami and Hirohisa Omura \\ Institute of Food Chemistry, Faculty of Agriculture, \\ Kyushu University 46-09, Fukuoka 812, Japan.
}

(Received March 18, 1988)

\begin{abstract}
The effects of $\mathrm{x}$-carrageenan $(\mathrm{KC})$, sodium alginate (SA), xanthan gum (XG) and $\mathrm{XG}$ /locust bean gum $(\mathrm{XG}+\mathrm{LG})$ mixture on rheological properties and microstructure of soy protein isolate (SPI) emulsion gels were investigated. Rheological properties were determined with texture profile analysis, breaking test and creep-recovery curve analysis. KC increased the hardness and instantaneous elastic modulus, and showed the most effectiveness on the gels. While, XG showed the lowest effect on hardness. $\mathrm{XG}+\mathrm{LG}$ addition gave the maximum in breaking force and deformation at heating from 20 to $60 \mathrm{~min}$. Scanning electron microscope was used to evaluate the changes in the microstructure of SPI-emulsion gels with polysaccharides. Preparations were carried out by critical point drying and cryofracturing methods. The fat droplets in the gels were not thoroughly fixed by glutaraldehyde and it was shown that they were dislodged from the fractured surfaces, leaving vacuoles, These observations also showed a wide variation among emulsion gels with various polysaccharides on a microstructural basis, which may be correlated to rheological properties.
\end{abstract}

\section{INTRODUCTION}

Polysaccharides are used in the food industry as texture modifying agents in many types of products. They have a wide range of functional properties and are used for several different purposes, including as stabilizers, thickeners and structure forming (gelling) agents. For example, oil-in-water emulsion systems, polysaccharieds are widely used as stabilizers and emulsifier to prevent creaming and coalescence. Such as, xanthan gum or sodium alginate is used in the preparation of mayonnaise and salad cream. Lippi and Taranto (1980) reported that emulsifying activity and stability of soy protein isolate (SPI) could be improved by addition of sodium alginate. The effect of xanthan gum upon the rheological properties and stability of oil-in-water emulsion was evaluated by Hennock et al. (1980). In the heat-induced gelation of emulsion meat products, such as frankfurters and sausage, xanthan gum was more effective than carrageenan, locust bean gum and low methoxy pectin in preventing water loss from a low-fat meat emulsion (Wallingford and Labuza, 1983), and both xanthan gum and carrageenan were shown to stabilize the texture of frankfurters held in a vinegar pickle (Fox et al., 1983). These reports suggested that select gums were compatible with meat batters. Foegeding and Ramsey (1986) studied the effect of seven gums on

\footnotetext{
*Reprint requests to H. 0 .
} 
stability and textural properties of low-fat meat batters. Changes of rheological and water-holding ability of gelled meat batters containing gums after various heating temperature were also investigated by them (1987), and the results indicated that gums were specific in affecting texture and water-holding ability.

The scanning electron microscope (SEM) is a relatively new research tool which allows scientists to view specimens at very high resolution with three dimensional detail. Theno and Schmidt (1978) were the first among scientists who made an effort to establish whether or not a meat emulsion is a true one in SEM micrographs of meat emulsion. These researchers compared microstructures of three commercial frankfurters and concluded that they are true meat emulsions. The microstructure of liver sausage was evaluated by Ray et al. (1981). Basgall et al. (1983) also reported an alternative to critical point drying method for preparing meat emulsion for SEM. However, researches with SEM to correlate the rheological properties and microstructure had been very limited thus far with respect to emulsion products. The purpose of this study was to evaluate the effects of several polysaccharides and heating time on rheological properties and microstructure of the SPI-emulsion gels.

\section{MATERIALS AND METHODS}

\section{M aterials}

Soy protein isolate (SPI) was purchased from Fuji Oil Co., Ltd. and salad oil from Nissin Saled Oilmills Ltd. Sodium alginate (SA), x-carrageenan (KC), xanthan gum (XG), and locust bean gum (LG) were guaranteed grade reagents obtained from Wako Pure Chemical Industries Ltd.

\section{Preparation of emulsion gels}

Forty grams of SPI was mixed with $200 \mathrm{ml}$ of $0.25 \%(\mathrm{w} / \mathrm{v})$ polysaccharides solution, and then $60 \mathrm{ml}$ of salad oil were added slowly to the protein/polysaccharide mixtures under continuous mixing in a mixer (MK-6000, Matsushita Electric Co., Ltd.). The emulsions were then transferred to the casing (Teepak. Wienie-Pak Co., diameter $=21.4 \mathrm{~mm}$ ) and stood at $4^{\circ} \mathrm{C}$ for 1 day. The emulsions were heated at $80^{\circ} \mathrm{C}$ for various time. After heating, the samples were removed from water bath and allowed to stand in tap water for cooling to approximately $15^{\circ} \mathrm{C}$. The gels were left overnight at $4^{\circ} \mathrm{C}$. Prior to measuring the rheological properties, the gels were equilibrated at $20^{\circ} \mathrm{C}$ for $1 \mathrm{hr}$.

\section{Determination of rheological properties}

(1) Texture profile analysis

Textural characteristics of the emulsion gels were measured with a rheometer (Rheoner RE-3305, Yamaden Co., Ltd.) by means of General Food objective texture profile analysis. The speed of the moving stage was set at $1 \mathrm{~mm} / \mathrm{sec}$ in both upward and downward directions. The compression ratios of the cylindrical specimen $(20 \mathrm{~mm}$ in height, $23 \mathrm{~mm}$ in diameter) were $15 \%$ deformation. A full scale load range of 199.9 $\mathrm{g}$ was used and two consecutive bites were taken. The textural characteristics such as hardness, cohesiveness and adhesiveness were evaluated according to Bourne's definition (1978). 
Each estimation was performed at least five times in duplicated samples and data obtained were averaged.

(2) Determination of breaking parameters

The breaking parameters of emulsion gels were measured with a rheometer at a constant table speed of $1 \mathrm{~mm} / \mathrm{sec}$ using a spherical plunger with diameter of $5 \mathrm{~mm}$ for the sample of $20 \mathrm{~mm}$ height. From a force-deformation curve, two parameters were obtained, breaking force was defined as the force at the breaking point (g) and breaking deformation at the breaking point (mm), according to Toda et al. (1971).

(3) Creep-recovery curve analysis

The creep-recovery curve analysis was performed with a rheometer as recommended by Mohseinin and Mittal (1977). Moving stage speed was $1 \mathrm{~mm} / \mathrm{sec}$ on a constant force. Such a compression involved linear $15 \%$ of the $3 \mathrm{~mm}$ height of the cylindrical gels, and tests were carried out at $20^{\circ} \mathrm{C}$. The viscoelastic parameters such as instantaneous elastic modulus, retarded elastic modulus, viscosity and time, and permanent viscosity were obtained.

\section{Preparations of gel for scanning electron microscopy (SEM)}

Samples were prepared by cutting to a piece with $2 \times 2 \mathrm{~mm}$ surface from the center of each SPI-emulsion gels with a razor blade, followed by two different methods for SEM : (1) critical point drying and (2) cryofracturing.

(1) Critical Point drying method: The procedure of Jones and Mandigo (1982) was used with slight modifications. Emulsion gel specimens from each treatment were fixed in $2 \%$ glutaraldehyde using a $0.1 \mathrm{M}$ phosphate buffer $(\mathrm{pH} 7.2)$ for $12 \mathrm{hr}$ at $4^{\circ} \mathrm{C}$, followed by three washings with $0.1 \mathrm{M}$ phosphate buffer $(\mathrm{pH} 7.2$ ). All specimens were then post-fixed for $6 \mathrm{hr}$ in 1.0\% osmium tetroxide solution (phosphate buffered), and followed by three more washing with $0.1 \mathrm{M}$ phosphate buffer. Specimens were then dehydrated in graded series of ethanol of $60,70,80,90 \%$, and three changes of $100 \%$ for $10 \mathrm{~min}$ each and treated with isoamyl acetate for $1 \mathrm{hr}$. Samples were applied to critical point drying with liquid $\mathrm{CO}$, as the transitional medium (HCP-1, Hitachi Co.). Each piece was then broken such that the broken side would used for SEM observation.

(2) Cryofracturing method: The procedure of Edward et al. (1983) was also used with slight modifications. Emulsion gel specimens were immersed in liquid nitrogen, and cryofractured by sharply striking with a precooled metal blade. Samples were immediately removed from the liquid nitrogen and fixed in $2 \%$ glutaraldehyde fixative buffered with $0.1 \mathrm{M}$ phosphate buffer $(\mathrm{pH} 7.2)$ for $12 \mathrm{hr}$ at $4^{\circ} \mathrm{C}$. In order to preserve the protein matrix, all the samples were fixed and were post-fixed with $1 \%$ osmium tetroxide solution for $1 \mathrm{hr}$ to stabilize the lipid. After fixation, the samples were washed for three times with $0.1 \mathrm{M}$ phosphate buffer. Samples were dehydrated in a graded ethanol series of $25,50,75,90,100,100$, and 100\% (ethanol : water, v/v) for 10 min at $25^{\circ} \mathrm{C}$, followed by a graded Freon 113 series of 25, 50, 75, 90, 100, 100, and 100\% (Freon 113 : ethanol, v/v) for $10 \mathrm{~min}$ each at $25^{\circ} \mathrm{C}$. The samples were dried in a vacuum desiccator attached to a running water aspirator for $12 \mathrm{hr}$.

The dried specimens were mounted on $15 \mathrm{~mm}$ aluminum stubs with double-sided adhesive tape and silver paint for increased conductivity. Then, specimens were coated with gold, by applying with a diode sputtering unit (HUS-4GB, Hitachi Co.). The specimens were viewed under a scanning electron microscope (MSM-6, Akashi 
Co.) operated at an accelerating voltage of $20 \mathrm{KV}$, at $5000 \mathrm{x}$ magnification. An average of five places from each treatment was observed in order to obtain representative micrographs.

\section{RESULTS AND DISCUSSION}

\section{Textural characteristics of SPI-emulsion gels with polysaccharides}

The effects of $0.25 \%(\mathrm{w} / \mathrm{v}) \mathrm{KC}, \mathrm{SA}, \mathrm{XG}$ and XG+LG (1: 1) mixtures on texture

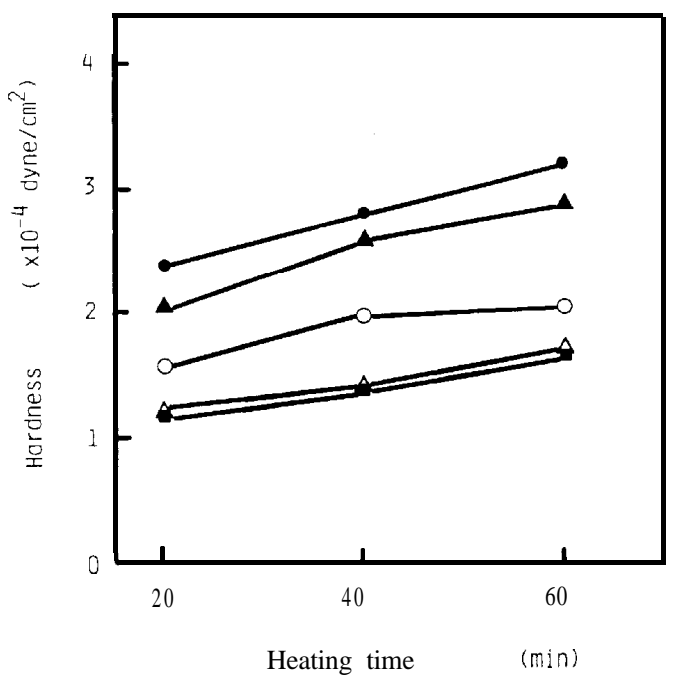

Fig. 1. Effect of heating time and different polysaccharides on hardness of SPIemulsion gels.

: control, $\bigcirc \mathrm{KC}, \mathrm{O}: \mathrm{SA}, \triangle: \mathrm{XG}, \mathrm{A}: \mathrm{XG}+\mathrm{LG})$

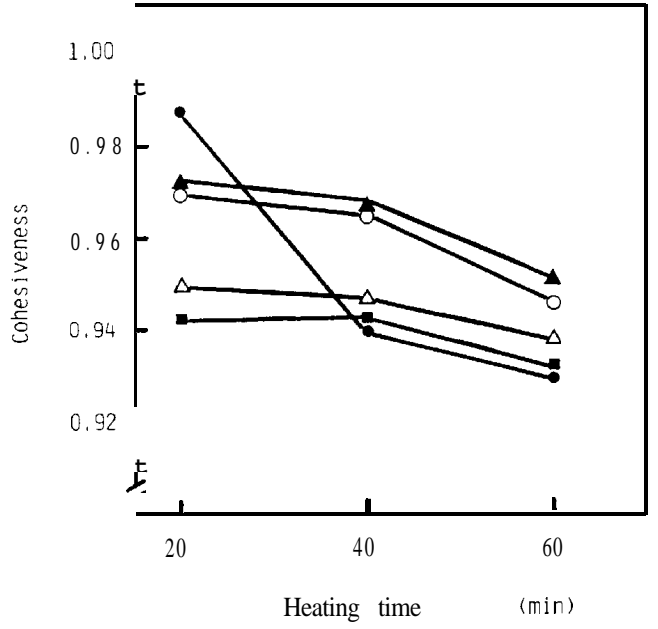

Fig. 2. Effect of heating time and different polysaccharides on cohesiveness of SPIemulsion gels. (See Fig. 1 for symbols) 
of SPI-emulsion gels were studied. As shown in Fig. 1, the hardness increased by all treatments at heating time from 20 to $60 \mathrm{~min}$. Analysis of data obtained indicated that a significant differences among them were observed. All samples with polysaccharides showed hardness greater than that of control (polysaccharides-free), and no differences were shown between the XG and control-samples. KC-samples became the most hardest by heating from 20 to $60 \mathrm{~min}$ and showed 2 times higher than control, at heating $60 \mathrm{~min}$. It indicated that the $\mathrm{KC}$ had the most effect on hardness of emulsion gels.

In the cohesiveness determination of the gels (Fig. 2), the XG+ LG-sample gave values higher than the other samples, except at heating $20 \mathrm{~min}$. And, it was showed that almost the values decreased slightly accompanying heating time. But, the values of KC-sample decreased sharply at heating $40 \mathrm{~min}$, and from this point the minimum was obtained.

As shown in Fig. 3, the adhesiveness varied a little with elongation of heating time. The control-sample exhibited the remarkably decrease by about $75 \%$ for heating from 20 to $60 \mathrm{~min}$. The addition of $\mathrm{KC}$ resulted in increase with elongation of heating time. However, the other samples showed a decrease tendency during heating from 40 to $60 \mathrm{~min}$.

\section{Breaking parameters of SPI-emulsion gels with polysaccharides}

Breaking test involves measuring either the depth of penetration of a body sinking into the gels, and the force required to push a penetrating body into a gels at a constant speed. The results of breaking test are shown in Figs. 4 and 5. The breaking force of the gels with polysaccharides as a function of heating time was shown in Fig. 4. XG+ LG-sample showed the highest resistance to penetration and control-sample gave the lowest value at heating from 20 to $60 \mathrm{~min}$. These observations indicated that the gels with polysaccharides showed a significantly higher breaking force than that of without

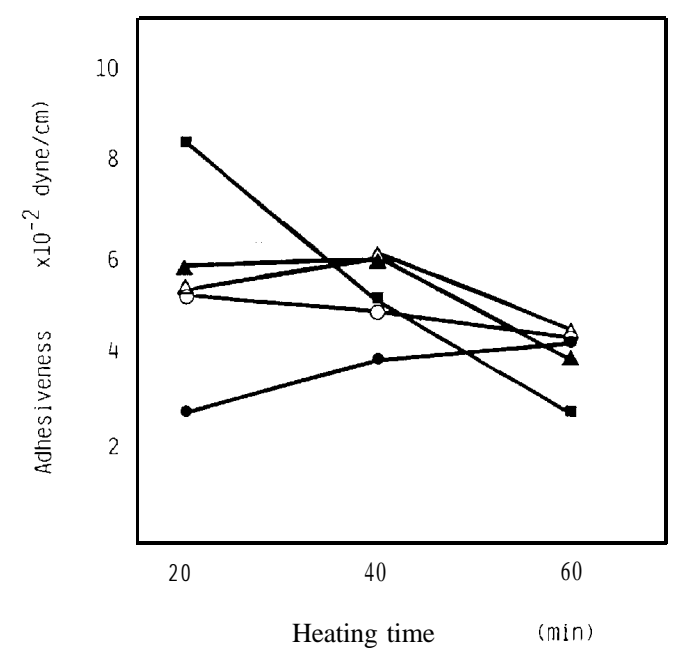

Fig. 3. Effect of heating time and different polysaccharides on adhesiveness of SPIemulsion gels. (See Fig. 1 for symbols) 
polysaccharides after various heating time. Also, these results showed that the values increased slightly with elongation of heating time in all samples. The order of the value was $\mathrm{XG}+\mathrm{LG}>\mathrm{KC}>\mathrm{XG}>\mathrm{SA}>$ control.

The breaking deformation was shown in Fig. 5. Similarly, the XG+LG-sample showed the highest value, and the control-sample exhibited the second one higher than the other samples. In XG, KC and SA-samples, the values decreased with elongation of heating time, but $S A$-sample showed slightly increased at heating for $60 \mathrm{~min}$. The order of the value was $\mathrm{XG}+\mathrm{LG}>$ control $>\mathrm{XG}>\mathrm{KC}>\mathrm{SA}$.

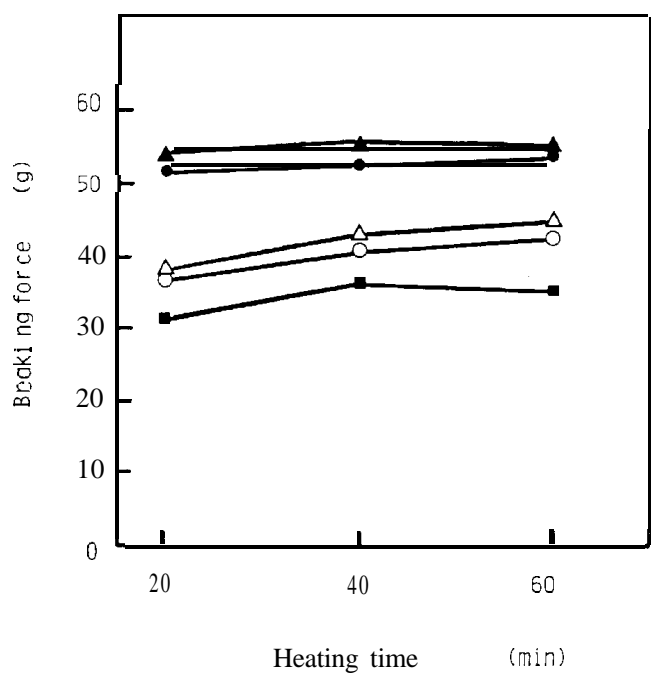

Fig. 4. Effect of heating time and different polysaccharides on breaking force of SPI -emulsion gels. (See Fig. 1 for symbols)

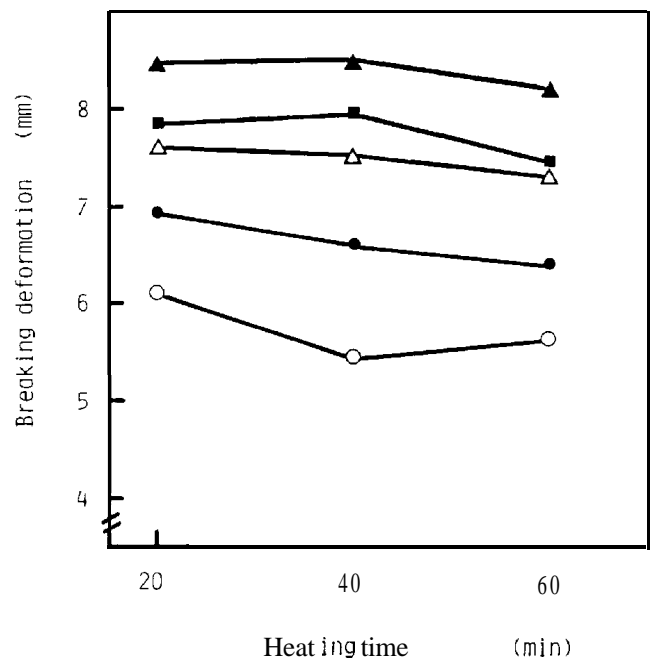

Fig. 5. Effect of heating time and different polysaccharides on breaking deformation of SPI-emulsion gels. (See Fig. 1 for symbols) 


\section{Creep compliance curves for SPI-emulsion gels with different polysaccha- rides and heating time}

Fig. 6 showed the creep compliance curves of the SPI-emulsion gels with control, $\mathrm{KC}$, SA, XG and XG+LG after heating for 20, 40 and $60 \mathrm{~min}$, respectively. The results showed an evident similarity among all samples. The curves essentially consist of two parts. When a fixed stress was applied, the elastic compliance rose instantaneously to a value $J_{0}$, equal to reciprocal of the instantaneous elastic modulus. After that, there was a time dependence build up which consists of the equilibrium compliance and the viscous compliance. It wsa found that the creep compliance curves could be fitted by a model consisting of a Maxwell element in series with one or more Voigt elements as described by the following equation :

$$
J(t)=J_{0}+J_{i}\left(1-e^{-t / \tau_{k 1}}\right)+t / \eta_{\mathrm{N}}
$$

where $J_{\mathrm{o}}$ is the instantaneous elastic compliance, $J_{1}$ is the retarded elastic modulus, $\tau_{\mathrm{k} 1}$ is the retardation time associated with the Voigt elements, and $\eta_{\mathrm{N}}$ is the Newtonian viscosity of Maxwell dashpot. The results illustrated that the compliance values decreased with elongation of heating from 20 to $60 \mathrm{~min}$ for all samples, and the facts indicated that gels' elastic properties were enhanced and became more viscous flow characteristics by heating and resulted in the changes of gels network structures.

\section{Viscoelastic parameters of SPI-emulsion gels with polysaccharides}

All the SPI-emulsion gels exhibited viscoelasticity with or without polysaccharides under the test conditions applied. And, all the samples in this experiment were considered six-elements. The results from creep-recovery curves was shown in Tables $1 \sim 3$, indicating the effect of polysaccharides on SPI-emulsion gels which heated at $80^{\circ} \mathrm{C}$ for 20,40 and $60 \mathrm{~min}$, respectively. The $\mathrm{KC}$-sample showed the maximum instantaneous elastic modulus $\left(E_{0}\right)$ and control-sample showed the minimum. The order of the value was $\mathrm{KC}>\mathrm{XG}+\mathrm{LG}>\mathrm{SA}>\mathrm{XG}>$ control, unlike hardness and breaking force. Also, the results indicated that $E_{\mathrm{o}}$ values increased with elongation of heating time, since all the samples showed the instantaneous elastic modulus with $10^{5}$ dyne $/ \mathrm{cm}^{2}$ order and Newtonian viscosity with $10^{8} \mathrm{dyne} / \mathrm{cm}^{2}$ order, it was illustrated that those gels have as cross-linked rubber-like materials.

The effect of polysaccharides on viscoelastic deformation of gels was also shown in Tables $1 \sim 3$. The deformation proportion was combined with instantaneous, retarded and permanent deformations. It was shown that no regular variation of retarded and permanent deformation by heating was observed for all the samples. However, the instantaneous deformation proportion decreased with heating time from 20 to $60 \mathrm{~min}$ for any samples. This means that with elongation of heating time, the elastic properties of gels could be enhanced and became more resistant against the force applied to prevent the deformation of gels.

\section{Scanning electron microscopic structure}

Microstructures of emulsion gels with polysaccharide were observed by SEM. Figs. 7-1, 2a, 2b, Figs. 7-3a, 3b and Figs. 7-4a, 4b showed the micrographs of control, $\mathrm{XG}+\mathrm{LG}$ and SA-samples, respectively. Fig. 7-1 showed the fractured surface of control-sample which had been fixed solely with glutaraldehyde. A noticeable lipid 



Fig. 6. Creep compliance curves of the SPI-emulsion gels with different polysaccha. rides as function of heating time. (A : control, B: KC, C : SA, D : XG, E : XG+ LG) 
Table 1. Effect of polysaccharides on viscoelastic parameters and deformation of SPI-emulsion gels heating at $80^{\circ} \mathrm{C}$ for $20 \mathrm{~min}$.

\begin{tabular}{lccccc}
\multicolumn{1}{c}{ Polysaccharides } & CTL* & KC & XG & SA & XG $+\mathrm{LG}$ \\
\hline$E_{0}\left(\right.$ dyne $\left.\cdot \mathrm{cm}^{-2} \times 10^{-5}\right)$ & $\mathbf{0 . 6 9}$ & 1.67 & 0.79 & 1.00 & 1.12 \\
$E_{1}\left(\right.$ dyne $\left.\cdot \mathrm{cm}^{-2} \times 10^{-5}\right)$ & 2.53 & 4.98 & 2.83 & 4.89 & 4.79 \\
$\eta_{1}\left(\right.$ poise $\left.\times 10^{-7}\right)$ & 2.28 & 5.61 & 2.92 & 4.59 & 4.44 \\
$\tau_{k 1}(\mathrm{sec})$ & 90.0 & 112.7 & 103.2 & 93.9 & 92.7 \\
$E_{2}\left(\right.$ dyne $\left.\cdot \mathrm{cm}^{-2} \times 10^{-5}\right)$ & 4.00 & 7.27 & 3.61 & 5.64 & 6.91 \\
$\eta_{2}\left(\right.$ poise $\left.\times 10^{-6}\right)$ & 5.36 & 7.06 & 3.86 & 5.42 & 7.02 \\
$\tau_{k 2}(\mathrm{sec})$ & 13.4 & 9.7 & 10.7 & 9.6 & 10.2 \\
$\eta_{\mathrm{N}}\left(\right.$ poise $\left.\times 10^{-8}\right)$ & 2.14 & 4.36 & 2.07 & 4.19 & 3.82 \\
Deformation $(\%)$ & & & & & \\
$\quad$ Instantaneous & 59.9 & 55.8 & 57.6 & 64.9 & 63.6 \\
$\quad$ Retarded & 29.1 & 31.4 & 29.3 & 25.8 & 25.4 \\
$\quad$ Permanent & 11.0 & 12.8 & 13.1 & 9.3 & 11.0 \\
\hline
\end{tabular}

* CTL : Control.

Table 2. Effect of polysaccharides on viscoelastic parameters and deformation of SPI-emulsion gels heating at $80^{\circ} \mathrm{C}$ for $40 \mathrm{~min}$.

\begin{tabular}{lccccc}
\multicolumn{1}{c}{ Polysaccharides } & CTL* & KC & XG & SA & XG+LG \\
\cline { 1 - 4 }$E_{0}\left(\right.$ dyne $\left.\cdot \mathrm{cm}^{-2} \times 10^{-5}\right)$ & 0.79 & 2.11 & 1.05 & 1.32 & 1.53 \\
$E_{1}\left(\right.$ dyne $\left.\cdot \mathrm{cm}^{-2} \times 10^{-5}\right)$ & 2.24 & 6.54 & 2.51 & 4.19 & 4.92 \\
$\eta_{1}\left(\right.$ poise $\left.\times 10^{-7}\right)$ & 2.15 & 6.26 & 2.10 & 4.06 & 5.10 \\
$\tau_{k 1}(\mathrm{sec})$ & 95.9 & 95.7 & 83.8 & 97.0 & 103.7 \\
$E_{2}\left(\right.$ dyne $\left.\cdot \mathrm{cm}^{-2} \times 10^{-5}\right)$ & 2.62 & 10.5 & 4.12 & 5.03 & 7.11 \\
$\eta_{2}\left(\right.$ poise $\left.\times 10^{-6}\right)$ & 2.68 & 9.74 & 3.69 & 4.70 & 6.84 \\
$\tau_{k 2}(\mathrm{sec})$ & 10.2 & 9.3 & 8.9 & 9.4 & 4.6 \\
$\eta_{\mathrm{N}}\left(\right.$ poise $\left.\times 10^{-8}\right)$ & 3.69 & 4.12 & 1.83 & 4.39 & 4.49 \\
Deformation $(\%)$ & & & & & \\
$\quad$ Instantaneous & 56.4 & 54.3 & 49.5 & 56.8 & 57.7 \\
$\quad$ Retarded & 36.5 & 29.2 & 33.4 & 33.0 & 30.6 \\
$\quad$ Permanent & 7.1 & 16.5 & 17.1 & 10.2 & 11.7 \\
\hline
\end{tabular}

* CTL : Control.

Table 3. Effect of polysaccharides on viscoelastic parameters and deformation of SPI-emulsion gels heating at $80^{\circ} \mathrm{C}$ for $60 \mathrm{~min}$.

\begin{tabular}{|c|c|c|c|c|c|}
\hline Polysaccharides & $\mathrm{CTL}^{*}$ & KC & XG & SA & $\mathrm{XG}+\mathrm{LG}$ \\
\hline$E_{0}\left(\right.$ dyne $\left.\cdot \mathrm{cm}^{-2} \times 10^{-5}\right)$ & 1.22 & 2.23 & 1.30 & 1.44 & 1.66 \\
\hline$E_{1}\left(\right.$ dyne $\left.\cdot \mathrm{cm}^{-2} \times 10^{-5}\right)$ & 2.08 & 6.02 & 2.46 & 4.29 & 4.89 \\
\hline$\eta_{1}\left(\right.$ poise $\left.\times 10^{-7}\right)$ & 2.10 & 7.51 & 3.07 & 4.35 & 6.98 \\
\hline$\tau_{k 1}(\mathrm{sec})$ & 104.1 & 124.8 & 125.0 & 101.3 & 106.5 \\
\hline$E_{2}\left(\right.$ dyne $\left.. \mathrm{cm}^{-2} \times 10^{-5}\right)$ & 5.03 & 12.3 & 4.30 & 5.39 & 6.98 \\
\hline$\eta_{2}\left(\right.$ poise $\left.\times 10^{-6}\right)$ & 6.08 & 13.8 & 3.39 & 5.77 & 7.22 \\
\hline$\tau_{k 2}(\mathrm{sec})$ & 12.1 & 11.3 & 7.9 & 10.7 & 10.3 \\
\hline$\eta_{\mathrm{N}}\left(\right.$ poise $\left.\mathrm{x} 10^{-8}\right)$ & 1.79 & 3.72 & 3.14 & 5.58 & 4.07 \\
\hline \multicolumn{6}{|l|}{ Deformation (\%) } \\
\hline Instantaneous & 44.3 & 52.7 & 48.4 & 57.0 & 55.1 \\
\hline Retarded & 37.8 & 28.4 & 39.7 & 34.3 & 31.6 \\
\hline Permanent & 17.9 & 18.9 & 11.9 & 8.7 & 13.3 \\
\hline
\end{tabular}

* CTL : Control. 


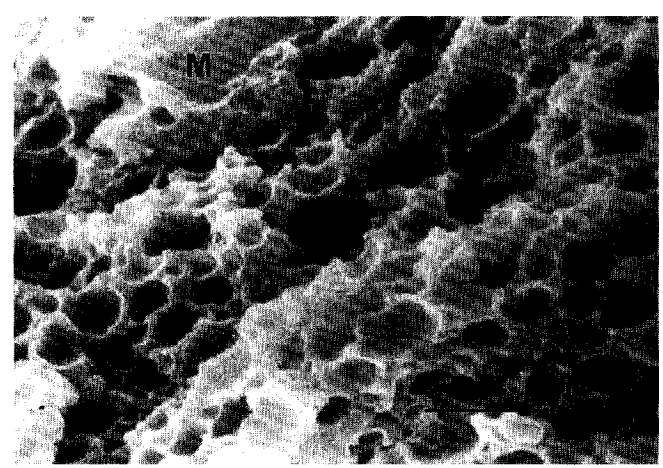

Fig. 7-1. Microstructure of SPI-emulsion gel (control). Sample was fixed with glutaraldehyde only, as followed by critical point drying.

$\mathrm{M}=$ protein matrix, $\mathrm{E}=$ empty vacuoles, Magnification $=5,000 \times, \mathrm{Bar}=5 \mu \mathrm{m}$.

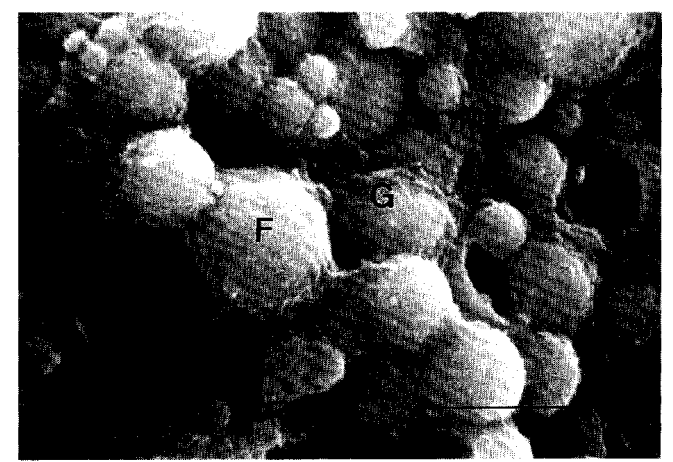

Fig. 7-2a. Microstructure of SPI-emulsion gel (control). Sample was fixed with glutaraldehyde and post-fixed with osmiun tetroxide, as followed by critical point drying.

$\mathrm{M}=$ protein matrix, $\mathrm{F}=$ fat droplet, $\mathrm{G}=$ protein encapsulated fat droplet, Magnification $=5,000 \times$, Bar $=5 \mu \mathrm{m}$.

material could not be observed, although the protein matrix was well preserved. The surface is pock-marked with empty voids, and a fine structure of protein matrix of the gels could be observed, but lipid could not.

Figs. 7-2a, 3a and $4 \mathrm{a}$ depict the fractured surfaces of control gel and those with $\mathrm{XG}+\mathrm{LG}$ and SA, respectively. They had been fixed in glutaraldehyde and post-fixed in osmium tetroxide to preserve the lipid structure followed by critical point drying. Both the protein and lipid component are well preserved. For control-sample, as shown in Fig. 7-2a, it is evident that a large number of round fat droplets was presented and size from $3.75 \mu \mathrm{m}$ to $0.6 \mu \mathrm{m}$ in diameter. The fat droplets are evenly distributed throughout the gel matrix, (F) denotes fat droplets. It was also presumed that oil droplets had been contained in most of empty voids, as shown in Fig. 7-1, but dissolved away, inducing variation of size during fixation in glutaraldehyde. As shown in Fig. 7-3a for XG + LG-sample, smaller globules of fat droplet were embedded in 


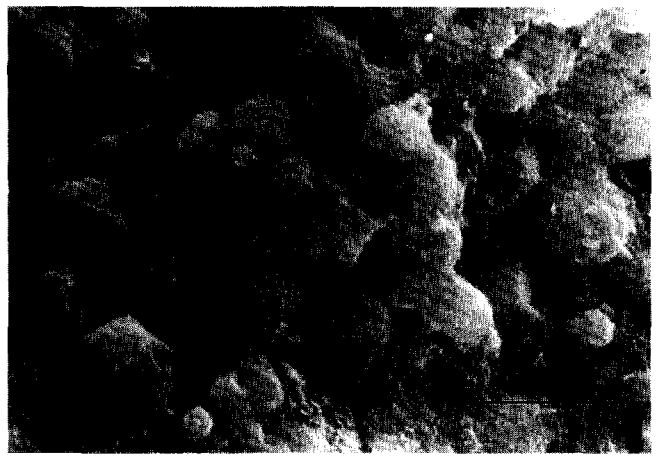

Fig. 7-3a. Microstructure of SPI-emulsion gel with XG + LG mixture. Sample was fixed with glutaraldehyde and post-fixed with osmiun tetroxide, as followed by critical point drying.

$\mathrm{M}=$ protein matrix, $\mathrm{F}=$ fat droplet, $\mathrm{G}=$ protein encapsulated fat droplet, Magnification $=5,000 \times$, Bar $=5 \mu \mathrm{m}$.

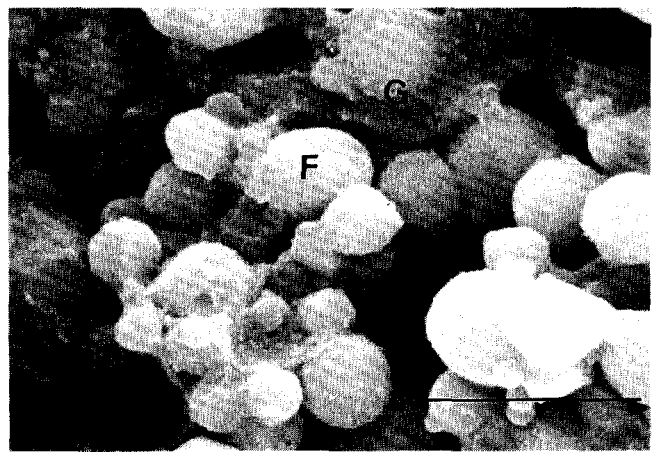

Fig. 7-4a. Microstructure of SPI-emulsion gel with SA. Sample was fixed with glutaraldehyde and post-fixed with osmiun tetroxide, as followed by critical point drying.

$M=$ protein matrix, $F=f a t$ droplet, $G=$ protein encapsulated fat droplet, Magnification $=5,000 \times$, Bar $=5 \mu \mathrm{m}$.

protein matrix, and the shape of droplets was not shown clearly, compared to control. The micrograph also reveals that a thick, dense protein-polysaccharides film surrounding by the fat droplet would be fixed with $\mathrm{OsO}_{4}$. SA-sample (Fig. 7-4a) indicated different structure compared to control and XG+ LG-sample. The micrograph revealed that the gel had a porous surface and fat droplets of irregular sizes which were filled in the textured structure. The fat droplets are bound into the protein matrix structure and appeared shiny.

The cryofractured surface of gels was then observed for control, XG+LG and SA -samples, respectively. As shown in Fig. 7-2b, the network structures of gel could be seen clearly and the fine structure of protein matrix is well preserved. It also appeared that well dispersed fat droplets were laden by protein matrix and small uniform round 




Fig. 7-2b. Microstructure of SPI-emulsion gel (control). Sample was cryofractured then fixed with glutaraldehyde and post-fixed with osmiun tetroxide, as followed by vacuum drying.

$\mathrm{M}=$ protein matrix, $\mathrm{F}=$ fat droplet, $\mathrm{G}=$ protein encapsulated fat droplet, Magnification $=5,000 \times$, Bar $=5 \mu \mathrm{m}$.

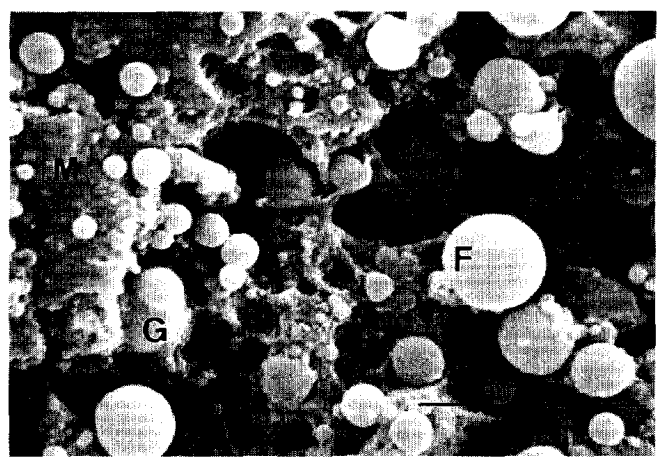

Fig. 7-3b. Microstructure of SPI-emulsion gel with XG+LG mixture. Sample was cryofractured then fixed with glutaraldehyde and post-fixed with osmiun tetroxide, as followed by vacuum drying.

$\mathrm{M}=$ protein matrix, $\mathrm{F}=$ fat droplet, $\mathrm{G}=$ protein encapsulated fat droplet, Magnification $=5,000 \times$, Bar $=5 \mu \mathrm{m}$.

fat droplet (F) were stood out from the exposed fracture face. XG+LG-sample was shown in Fig. 7-3b, the gel also showed that the fine protein matrix and fat droplets embedded partly in matrix. And, many number of larger and smaller droplets appeared to have been draw out from the exposed fracture face. SA-sample was shown in Fig. 7-4b, which was significant different from control and XG+ LG-sample, and the fat droplets were not as fine as that observed in the XG+LG-sample, but the droplets appear to be bound throughout the matrix.

From the observations in this experiment, it was found that the SPI-emulsion gels with polysaccharides would be firmer than the control-sample and suggested that either the protein, fat or both are interacting with the polysaccharides. Proteinpolysaccharide interactions was observed between anionic polysaccharides and casein, 


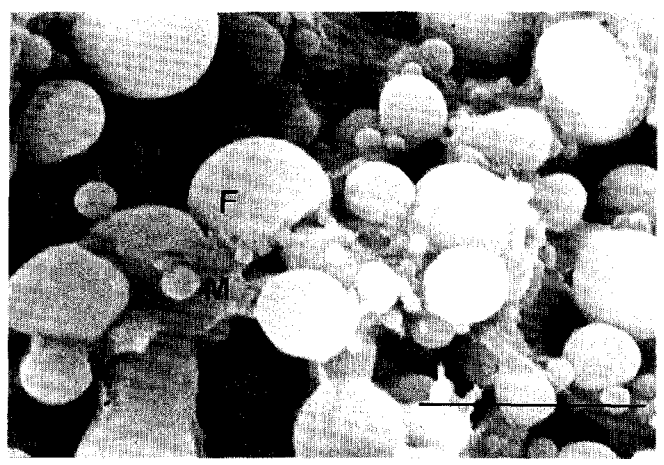

Fig. 7-4b Microstructure of SPI-emulsion gel with SA. Sample was cryofractured then fixed with glutaraldehyde and post-fixed with osmiun tetroxide, as followed by vacuum drying.

$\mathrm{M}=$ protein matrix, $\mathrm{F}=$ fat droplet, Magnification $=5,000 \times, \mathrm{Bar}=5 \mu \mathrm{m}$.

but not between casein and neutral polysaccharides (Elfak et al. 1979). Among polysaccharide-gels applied in this investigation, the $\mathrm{KC}$ added gel was the most resistance to compression force in contrast to control-sample, so that the $\mathrm{KC}$ seemed to be most effective to obtain the maximum hardness and instantaneous elastic modulus. This suggested that the sulfate groups in $\mathrm{KC}$ would interact strongly with protein, and resulted in increase of the rheological properties.

Xanthan gum has the unusual property of forming dimensionally stable gels in combination with locust bean gum (Rocks, 1971). It was observed that, for emulsion gels with $\mathrm{XG}+\mathrm{LG}$, the maximum cohesiveness and breaking force could be obtained, and hardness and instantaneous elastic modulus were the second. This may be attributed to the specific interaction of xanthan gum and locust bean gum. But, Foegeding and Ramsey (1986) reported that xanthan gum could interfered with the gelation process and significantly decreased all textural properties of meat batters. Similar findings were reported by Whiting (1984) who found that addition of 0.1 or $0.3 \%$ of xanthan gum to the frankfurter batters decreased cooking loses and gel strength. In our findings, the XG-sample showed the minimum for most of rheological parameters but a little harder than control.

In observation of emulsion gel structures by SEM, the use of osmium tetroxide post-fixation provides a quick method to distinguish protein from lipid in emulsion gel systems and may be useful for the examination of structural changes in the lipid and protein components of many food products. On the other hand, the use of critical point drying and cryofracturing methods dipict different micrographs, and these may be caused by the different method of procedure of SEM observation.

\section{ACKNOWLEDGEMENTS}

The authors thank Dr. Noboru Fujihara, Department of Animal Science, Faculty of Agriculture, Kyushu University, for permitting the use of the scanning electron microscope and giving much advice. 


\section{REFERENCES}

Basgall, E. J., P. J. Bechtel and F. K. Mckeith 1983 An alternative to critical point drying for preparing meat emulsions for scanning electron microscopy. Food Microsc., 2 :23-26

Bourne, M. C. 1978 Texture profile analysis. Food Tech., $7: 62-66$

Elfak, A. M., G. Pass and G. 0. Phillips 1979 The effect of casein on the viscosity of solutions of hydrocolloids. J. Sci. Food Agric., 30 : 994-998

Foegeding, E. A. and S. R. Ramsey 1986 Effect of gums on low-fat meat batters. J. Food Sci., 51: 33-36

Foegeding, E. A. and S. R. Ramsey 1987 Rheological and water-holding properties of gelled meat batters containing iota carrageenan, kappa carrageenan or xanthan gum. J. Food Sci., 52 : 549 553

Fox Jr, J. B., S. A. Ackerman and R. K. Jenkins 1983 Effect of anionic gums on the texture of pickled frankfurters. J. Food Sci., 48 :1031-1035

Hennock, M., R. R. Rahalkar and P. Richmond 1984 Effect of xanthan gum upon the rheology and stability of oil-water emulsions. J. Food Sci., 49: 1271-1274

Jones, K. W. and R. W. Mandigo 1982 Effects of chopping temperature on the microstructure of meat emulsions. J. Food Sci., $47: 1930-1935$

Lippi, M. S. and M. V. Taranto 1981 Soy protein-acidic polysaccharide interaction : Modification of the emulsification properties of soy protein isolate. Lebensm. -Wiss, u. Technol., 14: 55-59

Mohsenin, N. N. and J. P. Mittal 1977 Use of rheological terms and correlation of compatible measurements in food texture research. J. Texture Stud., $8: 395-408$

Ray, F. K., B. G. Miller, D. C. Van Sickle, E. D. Aberle, J. C. Forrest and M.D. Judge 1981 Microstructure of liver sausage. J. Food Sci., $46: 694-696$

Rocks, J. K 1971 Xanthan gum. Food Technol., $25: 476-485$

Theno, D. M. and G. R. Schmidt 1978 Microstructural comparisons of three commercial frankfurters. J. Food Sci., $43: 845-848$

Toda, J., T. Wada., K. Yasumatsu and K. Ishii 1971 Application of principal component analysis to food texture measurements. J. Texture Stud. 2: 207-219

Wallingford, L. and T. P. Labuza 1983 Evaluation of the water binding properties of food hydrocolloids by physical/chemical methods and in a low fat meat emulsion. J. Food Sci., $48: 1-5$

Whiting, R. C. 1984 Addition of phosphates, proteins, and gums to reduced-salt frankfurter batters. J. Food Sci., 49: 1355-1357 